\title{
Transplacental Stimulation of Lung Development in the Fetal Rabbit by 3,5-Dimethyl-3'-Isopropyl-L-Thyronine
}

\author{
Philip L. Ballard, Bradley J. Benson, Arlette Brehier, Janet P. Carter, \\ Barbara M. KRIZ, and Eugene C. Jorgensen, Cardiovascular Research \\ Institute and Departments of Pediatrics, Anatomy and Pharmaceutical Chemistry, \\ University of California, San Francisco, San Francisco, California 94143
}

A B S T RAC T The effect of thyroid hormone on maturation of fetal rabbit lung was studied with maternal treatment using 3,5-dimethyl-3'-isopropyl-Lthyronine (DIMIT), a synthetic analogue of triiodothyronine. To investigate the in vivo kinetics and distribution of DIMIT, we prepared $\left[{ }^{3} \mathrm{H}\right]$ DIMIT and injected both pregnant rats (18-21 d gestation) and rabbits ( $25 \mathrm{~d}$ gestation). In the rat, maximal concentrations of radioactivity in maternal plasma, fetal plasma, and amniotic fluid occurred within $10 \mathrm{~min}, \mathrm{l}-2 \mathrm{~h}$, and 4-6 h, respectively, after intramuscular injection. After $7 \mathrm{~h}$ the concentration of radioactivity in fetal plasma was 163 and $71 \%$ of the maternal level in rats and rabbits, respectively, indicating that DIMIT readily crosses the placenta.

We treated pregnant rabbits for 1-2 $\mathrm{d}$ with DIMIT in doses of $0.5-3 \mathrm{mg} / \mathrm{kg}$ per $\mathrm{d}$ and examined the fetuses at 26 and $27 \mathrm{~d}$ gestation. Treatment did not affect fetal growth or viability. In fetal liver, DIMIT increased the activity of NADPH cytochrome $c$ reductase by $64 \%$ and decreased the glycogen content by $73 \%$ compared to controls. The rate of choline incorporation by lung minces increased in a dose-dependent manner to a maximum of $+104 \%$ at $3 \mathrm{mg} / \mathrm{kg}$ DIMIT; this dose stimulated by $38 \%$ the activity of lung phosphatidic acid phosphatase (PAPase), a corticosteroid-responsive enzyme, but there was no increase in tissue PAPase activity at most lower doses of DIMIT that enhanced choline incorporation. Treated lungs had $38 \%$ less glycogen than controls, but there was no effect on tissue levels of DNA, protein, or phospholipid. DIMIT treatment increased the amount of total phospholipid $(+163 \%)$, saturated phosphatidylcholine $(+330 \%)$, and PAPase activity $(+134 \%)$ in lung lavage fluid. The DIMIT effects on both choline incorporation by lung

A preliminary report of some of these results has been published (1).

Received for publication 26 November 1979 and in revised form 25 January 1980. minces and phospholipid content of lavage fluid were substantially greater than what had occurred with an optimal dose of betamethasone.

DIMIT also increased corticosteroid binding capacity in fetal plasma and produced a dose-dependent increase (maximal threefold) in total and free corticoids of both maternal and fetal plasma. It is estimated that elevated endogenous corticoids probably account for less than one-third of the increases in phospholipid synthesis and secretion observed at the higher doses of DIMIT.

These data indicate that administration of DIMIT to pregnant rabbits accelerates maturation of the surfactant system in fetal lung. The magnitude of the effects on phospholipid synthesis and secretion, along with the minimal effect on PAPase activity in fetal lung tissue, suggest that thyroid hormones affect different biochemical processes from those influenced by glucocorticoids.

\section{INTRODUCTION}

Hyaline membrane disease in premature infants is associated with deficient amounts of pulmonary surfactant, the phospholipid-protein material that normally prevents atelectasis. The well-documented stimulation of surfactant synthesis by corticosteroids (2) has prompted studies of other hormones that could accelerate lung development. In 1973, Wu et al. (3) reported that in utero administration thyroxine $\left(\mathrm{T}_{4}\right)^{1}$ to fetal rabbits enhanced lung maturation as judged by lung lavage and morphologic studies. Comparable morphologic effects were also described in a preliminary report by Rooney and co-workers (4). Smith and Torday (5) reported that $\mathrm{T}_{4}$, like corticosteroids,

${ }^{1}$ Abbreviations used in this paper: CBG, corticosteroidbinding globulin; DIMIT, 3,5-dimethyl-3'-isopropyl-L-thyronine; PAPase, phosphatidic acid phosphatase; $\mathrm{T}_{3}$, triiodothyronine; $\mathrm{T}_{4}$, thyroxine. 
increased the rate of choline incorporation into lecithin by fetal rabbit lung cells in culture. In fetal sheep, Erenberg et al. (6) found that thyroidectomy was associated with a lower tracheal fluid lecithin:sphingomyelin ratio and immature lung morphology. Two studies of newborn human infants found lower cord plasma triiodothyronine $\left(\mathrm{T}_{3}\right)$ and $\mathrm{T}_{4}$ levels associated with hyaline membrane disease $(7,8)$, and there is one report of accelerated lung development after intra-amniotic administration of $\mathrm{T}_{4}$ to human fetuses (9). Recently, we identified high affinity binding sites for thyroid hormones in nuclei of fetal rabbit lung and cultured lung cells (10). These various observations are consistent with the proposal that the fetal lung is a direct target tissue for thyroid hormones.

Because iodothyronines do not readily cross the placenta in most species (11), studies with $T_{3}$ and $T_{4}$ require surgery and direct injection into the fetus. However, this approach apparently introduces stressrelated factors, inasmuch as previous reports indicate that surgery and injection of the rabbit fetus with saline increases plasma corticoids and stimulates phospholipid synthesis (12-16). The limited passage of $T_{3}$ and $T_{4}$ from mother to fetus also limits any potential application of these hormones in the human for treating fetal hypothyroidism or pulmonary immaturity.

In contrast to $T_{3}$ and $T_{4}$, the thyroid hormone analogue 3,5-dimethyl-3'-isopropyl-L-thyronine (DIMIT) is weakly bound by plasma thyroxine-binding globulin (17) and appears to readily cross the placenta in the rat (18-21). DIMIT is the most potent of the nonhalogenated thyronine analogues, exhibiting $\sim 20 \%$ the activity of $\mathrm{T}_{4}$ in the tadpole (22) and rat antigoiter (18) assays. In a recent study, Comite et al. (19) found that administration of DIMIT to pregnant rats, at doses which were not thyrotoxic to the mother, suppressed fetal thyrotropin levels and prevented propylthiouracilinduced fetal goiter. $T_{4}$ and $T_{3}$ also prevented fetal goiter, but only in doses that caused maternal hyperthyroidism. Benson et al. (20) reported that treatment of pregnant rats with DIMIT increased the activity of fetal, but not maternal, liver $T_{3}$ aminotransferase activity, whereas maternal treatment with $T_{3}$ had opposite effects. Kriz et al. (21) found that administration of DIMIT to pregnant rats caused precocious maturation of both subcellular structure and enzyme activities in fetal liver. These studies indicate that maternally administered DIMIT is thyromimetic in the fetal rat. In addition, they suggest a preferential effect of DIMIT in the fetal compartment.

In this study we have used DIMIT to examine the effects of thyroid hormone on fetal lung maturation. We studied the kinetics and distribution of $\left[{ }^{3} \mathrm{H}\right] \mathrm{DIMIT}$ in pregnant animals, and investigated the effects of maternal DIMIT treatment on growth, plasma corti- coids, liver biochemical parameters, and synthesis and secretion of pulmonary phospholipids in fetal rabbits.

\section{METHODS}

\section{Materials}

DIMIT was synthesized as described (18) and dissolved immediately before use at a concentration of $1 \mathrm{mg} / \mathrm{ml}$ in sterile $0.9 \%$ saline containing $0.02 \mathrm{~N} \mathrm{NaOH}$ and $10 \%$ ethanol (diluent). [ $\left.{ }^{3} \mathrm{H}\right] \mathrm{DIMIT}(\sim 104 \mathrm{mCi} / \mathrm{mmol})$ was prepared by high energy tritium exchange with the procedure of Hembree et al. (23) and was stored at a concentration of $25 \mu \mathrm{g} / \mathrm{ml}$ in methanol at $-20^{\circ} \mathrm{C}$. Before injection, samples were taken to dryness under $\mathrm{N}_{2}$ and redissolved in the same volume of diluent. Betamethasone was in the form of Celestone Soluspan (Schering Corp., Kenilworth, N. J.), which contains equal amounts of betamethasone acetate and betamethasone phosphate. $\left[1,2-{ }^{3} \mathrm{H}\right]$ Cortisol $(45.8 \mathrm{Ci} / \mathrm{mmol})$ and $\left[\right.$ methyl $\left.-{ }^{3} \mathrm{H}\right]-$ choline chloride $(69.5 \mathrm{Ci} / \mathrm{mmol})$ were obtained from $\mathrm{New}$ England Nuclear, Boston, Mass. Uniformly labeled $\left[{ }^{3} \mathrm{H}\right] \mathrm{di}-$ palmitoylphosphatidylcholine and lipids extracted from adult dog lung were gifts from Dr. L. Dobbs, University of California, San Francisco. All other chemicals were reagent grade and were obtained from commercial suppliers.

\section{Methods}

$\left[{ }^{3} \mathrm{H}\right] D I M I T$ studies. Pregnant Sprague-Dawley rats of $18-21 \mathrm{~d}$ gestation received intramuscular injections of $\left[{ }^{3} \mathrm{H}\right.$ ]DIMIT $(6 \mu \mathrm{g})$ under light ether anesthesia. At various intervals after injection the animals were anesthetized under ether, the fetuses removed, and samples of amniotic fluid, maternal blood (cardiac puncture), and fetal blood (decapitation) were taken in heparinized tubes. In one experiment, serial samples of maternal blood were obtained using the procedure of Upton (24) except for placement of the catheter in the carotid artery. Catheters were also placed in two pregnant New Zealand White rabbits of $25 \mathrm{~d}$ gestation, and serial blood samples were taken before and after injection of $\left[{ }^{3} \mathrm{H}\right]$ DIMIT $(\sim 90 \mu \mathrm{g})$. After $7 \mathrm{~h}$ the animals were killed with pentobarbital intravenously, and samples of blood and amniotic fluid were obtained as described above. Radioactivity in samples of plasma and amniotic fluid was determined by scintillation counting. In some experiments we extracted samples of fluid with $5 \mathrm{vol}$ of $n$-butanol, vortexing for $30 \mathrm{~s}$, and collecting the supernate by centrifugation. The extraction procedure was repeated twice, and the combined supernates were taken to dryness under $\mathrm{N}_{2}$ and redissolved in methanol. Recovery of radioactivity was determined and the samples were analyzed by thin-layer chromatography on silica gel plates (Whatman, Inc., Clifton, N. J., $250 \mu \mathrm{m}$, preabsorbent loading zone) with chloroform:methanol:concentrated ammonium hydroxide (20:10:1).

Studies in fetal tissues. Time-dated pregnant rabbits (term, $31 \mathrm{~d}$ ) received injections of DIMIT, diluent, or

\footnotetext{
${ }^{2}$ In these studies we used 10 different preparations of DIMIT. Similar results were obtained with each preparation except for one (I-98-2), which failed to increase the amount of lavage phospholipid in each of four experiments. This preparation of DIMIT was less soluble in diluent and was subsequently shown to contain $\sim 50 \%$ (by absorbance) of an unidentified contaminant. The data obtained with this lot of DIMIT were omitted from the results presented.
} 
betamethasone at the dosage schedule noted in the tables. In our first series of experiments, the animals were killed by pentobarbital intravenously at $26 \mathrm{~d}$ gestation, fetal lung and liver were removed, and plasma obtained as described above. The rate of $\left[{ }^{3} \mathrm{H}\right]$ choline incorporation into phosphatidylcholine by lung minces and the activity of phosphatidic acid phosphatase (PAPase, EC3.1.3.4) in lung homogenate were determined as described (25). Assays were performed on lung tissue from four to eight fetuses per litter, and residual tissue from each litter was pooled for assay of glycogen (26), protein (27), DNA (28), phospholipid (29), and saturated phosphatidylcholine (30). In some experiments, fetal liver was assayed for glycogen, and for glucose-6-phosphatase (31) and NADPH cytochrome $c$ reductase (32) in microsomal preparations (21).

In a second set of experiments, we sacrificed pregnant rabbits at $27 \mathrm{~d}$ gestation (control and DIMIT-treated) and at 30.5-31 d (control) for lavage of fetal lungs. Lungs were washed in situ through a tracheal cannula with seven aliquots of $0.7-2.6 \mathrm{ml} 0.9 \%$ saline. The washings from each litter (generally eight fetuses) were combined and centrifuged for $8 \mathrm{~min}$ at $700 \mathrm{~g}$ at $2^{\circ} \mathrm{C}$ to remove cells. Supernate was divided to provide duplicate samples which were centrifuged at $2^{\circ} \mathrm{C}$ for $150 \mathrm{~min}$ at $78,000 \mathrm{~g}$. Pellets were resuspended in water, a portion was frozen for assay of PAPase activity, ${ }^{3}$ and lipids were extracted from the remainder by the method of Folch et al. (33). Phospholipid phosphorus was assayed by a modification of the method of Baginski and Zak (34). Phospholipid composition was determined in pooled samples using two dimensional thin-layer chromatography (35) and the osmium tetroxide method of Mason et al. (30). After lavage, fetal lungs were dried for $72 \mathrm{~h}$ at $90^{\circ} \mathrm{C}$ under vacuum, and phospholipid and PAPase values were calculated per gram dry lung.

Studies in plasma. Plasma corticoids were assayed by competitive protein binding using charcoal adsorbant as described (36). DIMIT is inactive in this assay. The fraction of corticoids bound to corticosteroid binding globulin (CBG) was measured in $0.1 \mathrm{ml}$ undiluted plasma using charcoal adsorption (36), and CBG capacity was estimated by the same method after addition of $60 \mathrm{ng}$ cortisol to plasma samples. Albumin was assayed by the dye-binding procedure of Doumas et al. (37). Free (unbound) corticoids were calculated from the above values as described by $T$ ait and Burnstein (38).

Statistics. Unless otherwise noted, all values are expressed as mean \pm SE. Statistical significance was evaluated by unpaired $t$ test and by least squares linear regression.

\section{RESULTS}

Injection of $\left[{ }^{3} \mathrm{H}\right] D I M I T$. To investigate the distribution of DIMIT in pregnant animals, we performed pharmacokinetic studies with tritiated DIMIT. Because of a limited supply of this compound, most of the studies were performed in rats. Fig. 1 shows the concentration of radioactivity in plasma and amniotic fluid at various times after injection of $\left[{ }^{3} \mathrm{H}\right] \mathrm{DIMIT}$ to 12 pregnant rats. Radioactivity in maternal plasma was maximal at the first time point, $1 \mathrm{~h}$ after intramuscular injection; by $24 \mathrm{~h}$ the concentration of

\footnotetext{
${ }^{3}$ With storage of pellets at $-20^{\circ} \mathrm{C}$, PAPase activity decreased $\sim 6 \% / \mathrm{wk}$; the PAPase results presented here are corrected for loss caused by storage.
}

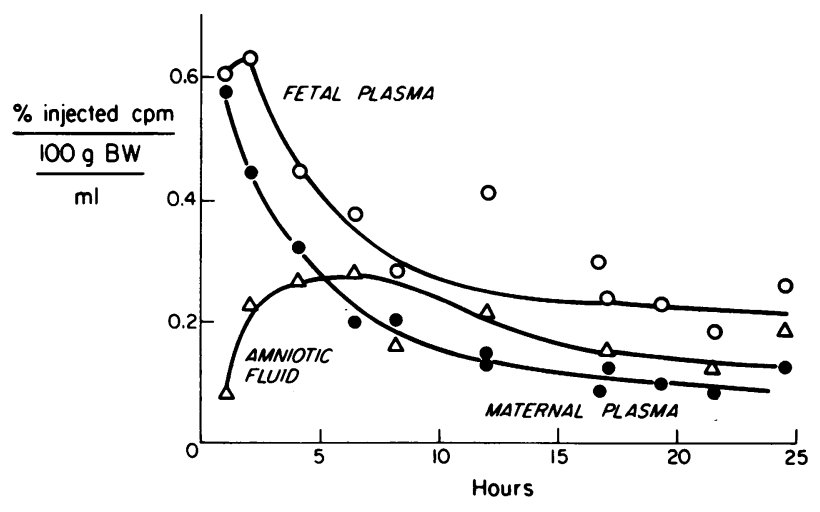

FIGURE 1 Concentration of radioactivity in maternal and fetal plasma and in amniotic fluid after injection of $\left[{ }^{3} \mathrm{H}\right] \mathrm{DIMIT}$ to pregnant rats. 12 animals of $18-21 \mathrm{~d}$ gestation received [ ${ }^{3}$ H]DIMIT $\left(1.3-2.1 \times 10^{6} \mathrm{cpm}\right)$ intramuscularly, and were killed at the intervals shown. The lines were constructed by visual inspection.

radioactivity in the maternal circulation was $15 \%$ of the value at $1 \mathrm{~h}$. The level of radioactivity was greater in fetal than maternal plasma at all time points; an approximate 2:1 fetal:maternal gradient occurred by 18-24 h. Peak levels of radioactivity developed later in amniotic fluid and the concentration remained lower than in fetal plasma. In one experiment with serial sampling of maternal blood, radioactivity was maximal $<10 \mathrm{~min}$ after injection and levels decreased with a time-course similar to that shown in Fig. 1.

In two experiments $\left[{ }^{3} \mathrm{H}\right] \mathrm{DIMIT}$ was administered to pregnant rabbits; serial samples of maternal blood were taken and the fetuses were obtained after $7 \mathrm{~h}$. Radioactivity in maternal plasma was maximal at 45 min and decreased to $34 \%$ of this value by $7 \mathrm{~h}$. Table I compares the distribution of radioactivity in maternal and fetal compartments of rats and rabbits $7 \mathrm{~h}$ after injection of $\left[{ }^{3} \mathrm{H}\right] \mathrm{DIMIT}$. The ratio of radioactivity in fetal and maternal plasma was 1.63 in rats and 0.71 in rabbits, indicating a species difference in the transplacental distribution and/or metabolism of DIMIT.

TABLE I

Distribution of Radioactivity $7 \mathrm{~h}$ after Administration of $\left[{ }^{3} \mathrm{H}\right]$ DIMIT to Pregnant Rats and Rabbits

\begin{tabular}{lcccc}
\hline & $\begin{array}{c}\text { Amniotic } \\
\text { fluid }\end{array}$ & $\begin{array}{c}\text { Maternal } \\
\text { plasma }\end{array}$ & $\begin{array}{c}\text { Fetal } \\
\text { plasma }\end{array}$ & $\begin{array}{c}\text { Fetal plasma: } \\
\text { maternal plasma }\end{array}$ \\
\hline \multicolumn{4}{c}{ \%cpm injected $100 \mathrm{~g}$ maternal body $w t^{-1} \mathrm{ml}^{-1}$} \\
Rat & $0.22 \pm 0.08$ & $0.20 \pm 0.01$ & $0.36 \pm 0.04$ & 1.63 \\
Rabbit & $0.26 \pm 0.03$ & $0.34 \pm 0.01$ & $0.24 \pm 0.02$ & 0.71 \\
\hline
\end{tabular}

Values are mean $\pm S D$ for experiments with two rats (19 d gestation) and two rabbits ( $25 \mathrm{~d}$ gestation). Rats received $\sim 1.5$ $\times 10^{6} \mathrm{cpm}(\sim 0.006 \mathrm{mg})$ and the rabbits received $\sim 23 \times 10^{6}$ cpm ( 0.09 mg). 
To examine for metabolism of $\left[{ }^{3} \mathrm{H}\right]$ DIMIT in vivo, maternal and fetal plasma samples from the studies described above were extracted with butanol and the extracts analyzed by thin-layer chromatography. Recovery of radioactivity in butanol was 71 and $79 \%$, and 63 and $62 \%$, in maternal and fetal plasma of rat and rabbit, respectively, compared to $80 \%$ for control plasma with added $\left[{ }^{3} \mathrm{H}\right]$ DIMIT. On thin-layer chromatography the amount of radioactivity migrating with nonradioactive DIMIT was identical for maternal and fetal samples $(61 \%$ for rat and $100 \%$ for rabbit). This suggests that $60-80 \%$ of the plasma radioactivity represents unmetabolized DIMIT, and that the proportion of radioactivity caused by authentic DIMIT is the same in maternal and fetal compartments of each species.

DIMIT effects in fetal rabbit tissues. Treatment of pregnant rabbits with $1 \mathrm{mg} / \mathrm{kg}$ DIMIT for $2 \mathrm{~d}$ did not affect fetal viability, birthweight, lung weight or water content at $26 \mathrm{~d}$ gestation (Table II). The crownrump length of treated fetuses was slightly greater with this dose of DIMIT, however, no effect on length was apparent at DIMIT doses of 0.5 or $3 \mathrm{mg} / \mathrm{kg}$, nor in $27-\mathrm{d}$ gestation fetuses receiving $1 \mathrm{mg} / \mathrm{kg}$ DIMIT. There was no apparent effect of treatment on the mothers.

In fetal liver, DIMIT treatment for $2 \mathrm{~d}$ increased the specific activity of NADPH cytochrome $c$ reductase $\left(3.55 \pm 0.33 \mathrm{nmol} \mathrm{min}^{-1} \mathrm{mg}\right.$ protein ${ }^{-1}$ vs. $2.17 \pm 0.21$, $P<0.05$, in control fetuses) and decreased the glycogen content $(0.047 \pm 0.015 \mathrm{mg} / \mathrm{mg}$ DNA vs. 0.175 $\pm 0.049, P<0.05$, in controls); similar effects have been reported in fetal rats (21). There was no effect of DIMIT on the specific activity of glucose-6-phosphatase, whereas an increase occurred in fetal rats treated for $5 \mathrm{~d}(21)$.

In fetal lung tissue, glycogen content in $26-\mathrm{d}$ gestation, DIMIT-treated fetuses was $1.10 \pm 0.08 \mathrm{mg} / \mathrm{mg}$ DNA compared to $1.76 \pm 0.11(P<0.05)$ in control fetuses. There was no effect of treatment on DNA, protein, or tissue phospholipid levels. Values in

TABLE II

Effect of DIMIT Treatment on Growth and Viability of Fetal Rabbits

\begin{tabular}{lccc}
\hline & Control & DIMIT* & $P$ \\
\hline Number of fetuses & 44 & 39 & \\
Birth weight, $g$ & $20.14 \pm 0.75$ & $22.8 \pm 0.4$ & NS \\
Length, $c m$ & $7.2 \pm 0.1$ & $7.6 \pm 0.1$ & $<0.005$ \\
Viability, \% & 97.8 & 95 & NS \\
Lung weight, $m g$ & $602.9 \pm 27$ & $659.1 \pm 19$ & NS \\
Lung water, \% & $87.34 \pm 0.4$ & $87.31 \pm 0.2$ & NS \\
\hline
\end{tabular}

Mean $\pm S E$ values for fetuses of five litters at $26 \mathrm{~d}$ of gestation are shown.

* Administered intramuscularly to pregnant does at dose of $1 \mathrm{mg} / \mathrm{kg}$ on day 24 of gestation and $0.5 \mathrm{mg} / \mathrm{kg}$ on day 25 . control and DIMIT-treated $(1.0,0.5 \mathrm{mg} / \mathrm{kg})$ fetuses, respectively, were DNA $63.3 \pm 0.8$ vs. $66.0 \pm 1.8 \mathrm{mg} / \mathrm{g}$ dry lung, protein $8.4 \pm 0.4$ vs. $7.88 \pm 0.46 \mathrm{mg} / \mathrm{mg}$ DNA, phospholipid $62.5 \pm 1.8$ vs $66.9 \pm 3.8 \mathrm{mg} / \mathrm{g}$ dry lung, and saturated phosphatidylcholine $11.2 \pm 0.4$ vs. $10.6 \pm 0.4$ $\mathrm{mg} / \mathrm{g}$ dry lung.

The effect of treatment on the rate of choline incorporation into lecithin by lung minces and on PAPase activity of lung homogenate are shown in Table III. Treatment with $0.05 \mathrm{mg} / \mathrm{kg}$ DIMIT did not affect choline incorporation, however, higher doses increased the rate of incorporation in a dose-dependent manner. Administration of $3 \mathrm{mg} / \mathrm{kg}$ DIMIT on day 24 , and $1.5 \mathrm{mg} / \mathrm{kg}$ on day 25 , enhanced choline incorporation by $104 \%$ compared to controls. Exposure to 1 $\mathrm{mg} / \mathrm{kg}$ for $24 \mathrm{~h}$ also caused a near doubling of incorporation. By comparison, maternal treatment with an optimal dose of betamethasone for $2 \mathrm{~d}$ increased the rate $61 \%$.

As shown in Table III, betamethasone administration also stimulated PAPase activity. In a previous study we demonstrated a close association between the levels of PAPase activity and choline incorporation in regard to dose of steroid, time-course of increase, and extent of stimulation (25). DIMIT treatment also increased PAPase activity in fetal lung homogenate, but only with two doses of $1 \mathrm{mg} / \mathrm{kg}$ or greater. With one dose of $1 \mathrm{mg} / \mathrm{kg}$ DIMIT, the rate of choline incorporation nearly doubled, whereas there was no effect on PAPase activity. The maximal increase with DIMIT $(3 \mathrm{mg} / \mathrm{kg})$ was $38 \%$ compared to $100 \%$ increase after betamethasone. These findings indicate that, in contrast to the effect of betamethasone, stimulation of choline incorporation by DIMIT treatment does not correlate closely with an increase in tissue PAPase activity.

The effect of DIMIT treatment on secretion of phospholipid was evaluated by lavage of $27 \mathrm{~d}$ gestation fetal lungs. Results for total phospholipid and PAPase activity after injection of diluent, DIMIT, or betamethasone are shown in Table IV. Treatment with one dose of DIMIT $24 \mathrm{~h}$ before delivery increased the phospholipid content of lavage fluid by $36 \%$, and $2 \mathrm{~d}$ of treatment produced a $163 \%$ increase. Exposure of fetuses to betamethasone for $2 \mathrm{~d}$ increased total phospholipids by about $50 \%$, in agreement with recent findings by Rooney et al. (16). For another index of surfactant content in lavage fluid, measurements of PAPase activity were obtained. It has been shown that phosphatase activity is present in lamellar bodies (39) and that the level in amniotic fluid correlates with the lecithin:sphingomyelin ratio (40), suggesting that, in addition to microsomal localization, PAPase is also associated with surface active material in both lung tissue and in alveolar spaces. Two doses of DIMIT produced a similar increase in both PAPase activity 
TABLE III

Effect of DIMIT and Betamethasone on Choline Incorporation and PAPase Activity in Lung Tissue of 26-d Gestation Rabbit Fetuses

\begin{tabular}{|c|c|c|c|c|}
\hline \multicolumn{3}{|c|}{ Treatment schedules } & \multirow[b]{2}{*}{ Choline incorporation } & \multirow[b]{2}{*}{ PAPase activity } \\
\hline & Day 24 & Day 25 & & \\
\hline & \multicolumn{2}{|c|}{$m g / k g$} & pmol mg wet lung ${ }^{-1} h^{-1}$ & nmol mg protein ${ }^{-1} \mathrm{~min}^{-1}$ \\
\hline Control & & & $\begin{array}{c}33.2 \pm 1.2^{*} \\
\quad(47)\end{array}$ & $\begin{array}{l}6.4 \pm 0.1^{*} \\
(35)\end{array}$ \\
\hline DIMIT & 0.05 & 0.05 & $\begin{array}{c}31.3 \pm 2.1 \\
\quad(12)\end{array}$ & $\begin{array}{c}6.5 \pm 0.4 \\
(8)\end{array}$ \\
\hline DIMIT & 0.5 & 0.25 & $\begin{array}{c}41.1 \pm 1.5 \ddagger \\
(30)\end{array}$ & $\begin{array}{l}6.2 \pm 0.3 \\
(12)\end{array}$ \\
\hline DIMIT & 1.0 & 0.5 & $\begin{array}{c}52.0 \pm 1.8 \ddagger \\
(30)\end{array}$ & $\begin{array}{l}7.1 \pm 0.2 \ddagger \\
(15)\end{array}$ \\
\hline DIMIT & - & 1.0 & $\begin{array}{c}63.0 \pm 3.2 \ddagger \\
(28)\end{array}$ & $\begin{array}{l}6.4 \pm 0.1 \\
(16)\end{array}$ \\
\hline DIMIT & 3.0 & 1.5 & $\begin{array}{c}67.8 \pm 4.0 \ddagger \\
(32)\end{array}$ & $\begin{array}{l}8.8 \pm 0.3 \ddagger \\
\quad(16)\end{array}$ \\
\hline $\begin{array}{l}\text { Betameth- } \\
\text { asone }\end{array}$ & 0.25 & 0.25 & $\begin{array}{c}53.3 \pm 2.1 \ddagger \\
(20)\end{array}$ & $\begin{array}{c}12.8 \pm 0.6 \ddagger \\
(16)\end{array}$ \\
\hline
\end{tabular}

All values are given as mean $\pm \mathrm{SE}$ with the number of fetal specimens shown in parentheses.

* Control values for all volumes of diluent administration were similar and were combined.

$\ddagger P<0.05$ compared to control.

$\$$ Data from reference 25 .

and phospholipid in lavage fluid, whereas betamethasone appeared to affect PAPase more than phospholipid. When individual PAPase values for all control and treated animals were plotted vs. the respective phospholipid values $(n=30)$, the regression equation was $y=28.9+68.9 x$ with $r=0.79$.

We also examined the composition of phospholipids in pooled lavage fluid from control fetuses at $27 \mathrm{~d}$

TABLE IV

Effect of DIMIT and Betamethasone Treatment on Phospholipid Content and PAPase Activity in Lung Lavage Fluid of 27-d Gestation Rabbit Fetuses

\begin{tabular}{|c|c|c|c|c|}
\hline \multicolumn{3}{|c|}{ Treatment schedule } & \multirow[b]{2}{*}{ Phospholipid } & \multirow[b]{2}{*}{ PAPase } \\
\hline & Day 25 & Day 26 & & \\
\hline & \multicolumn{2}{|c|}{$m g / k g$} & Mg Phosphorus'g dry lung & $n m o l h^{-1} g$ dry lung ${ }^{-1}$ \\
\hline Control & & & $\begin{array}{c}2.4 \pm 0.2 \\
(13)\end{array}$ & $\begin{array}{c}152 \pm 16 \\
(9)\end{array}$ \\
\hline DIMIT & - & 1.0 & $\begin{array}{c}3.4 \pm 0.4^{*} \\
(3)\end{array}$ & $\begin{array}{c}298 \pm 9^{*} \\
(2)\end{array}$ \\
\hline DIMIT & 1.0 & 1.0 & $\begin{array}{c}6.3 \pm 0.6^{*} \\
(8)\end{array}$ & $\begin{array}{c}355 \pm 42^{*} \\
(7)\end{array}$ \\
\hline $\begin{array}{l}\text { Betameth- } \\
\text { asone }\end{array}$ & 0.1 & 0.1 & $\begin{array}{c}3.7 \pm 0.3^{*} \\
(4)\end{array}$ & $\begin{array}{c}353 \pm 40^{*} \\
(4)\end{array}$ \\
\hline
\end{tabular}

Values are given as mean $\pm \mathrm{SE}$ with number of litters shown in parentheses.

$* P<0.05$ compared to control. 
TABLE V

Phospholipid Composition in Lavage Fluid of Control and DIMIT-Treated Fetal Rabbits

\begin{tabular}{|c|c|c|c|}
\hline \multirow[b]{2}{*}{ Phospholipid } & \multicolumn{2}{|c|}{ Control } & \multirow{2}{*}{$\begin{array}{l}\text { DIMIT-treated } \\
27 \mathrm{~d}\end{array}$} \\
\hline & $27 \mathrm{~d}$ & $30.5-31 \mathrm{~d}$ & \\
\hline & \multicolumn{3}{|c|}{ \% phospholipid phosphorus } \\
\hline Sphingomyelin & $28.4,29.2$ & $1.9, \quad 1.3 \ddagger$ & $14.5,29.2$ \\
\hline Phosphatidylcholine & $30.1,38.3$ & $68.6,75.9 \ddagger$ & $46.9,42.0 \S$ \\
\hline Saturated phosphatidylcholine & $17.2,22.2$ & $39.7,44.8 \ddagger$ & $31.4,33.2 \ddagger$ \\
\hline Phosphatidylethanolamine & $9.4,12.6$ & $6.3,5.0 \S$ & $8.6,14.5$ \\
\hline Phosphatidylglycerol & $0, \quad 1.0$ & $3.9, \quad 2.2 \S$ & $2.4, \quad 0.6$ \\
\hline \multicolumn{4}{|l|}{ Phosphatidylinositol } \\
\hline + Phosphatidylserine & $2.2, \quad 5.4$ & $9.0,9.7 \S$ & $5.5, \quad 3.9$ \\
\hline Lysophosphatidylcholine & $0, \quad 0$ & 0,0 & $\begin{array}{ll}1.6, & 1.2\end{array}$ \\
\hline \multicolumn{4}{|l|}{ Unidentified phospholipids* } \\
\hline Spot 1 & $4.2,0$ & 0,0 & $2.1,0.6$ \\
\hline Spot 2 & $0.9,0$ & $1.3,0$ & $1.5, \quad 0.6$ \\
\hline Spot 3 & $22.7, \quad 8.9$ & $8.9, \quad 5.2$ & $18.0,4.7$ \\
\hline
\end{tabular}

Phospholipids were separated by two-dimensional, thin-layer chromatography and osmium tetroxide, and assayed for phosphorus as described in Methods. Analyses were carried out on two batches of combined residual lavage fluids from 27 -d control fetuses (22 and 12 litters), 30.5-31 d control fetuses (2 and 2 litters) and 27-d DIMIT ( $1 \mathrm{mg} / \mathrm{kg}$, two doses) fetuses ( 11 and 3 litters). Individual values for each experiment are given.

* Spot 1 , near origin; spot 2 , near solvent front; spot 3 , with neutral lipids.

$\ddagger P<0.05$ vs. $27 \mathrm{~d}$ control.

$\$ P<0.2$ vs. $27 \mathrm{~d}$ control.

gestation, untreated fetuses of 30.5-31 d gestation, and 27-d fetuses exposed to two doses of DIMIT (Table V). With increasing gestational age, lavage fluid of untreated fetuses contained a greater percentage of phosphatidylcholine and saturated phosphatidylcholine, and a lower percentage of sphingomyelin. Treatment with DIMIT at $27 \mathrm{~d}$ gestation increased the percentage of saturated phosphatidylcholine in lavage fluid, consistent with accelerated lung maturation.

DIMIT effect on CBG and corticoids. We considered that the increase in PAPase activity of lung homogenate with higher doses of DIMIT might be caused by elevated levels of endogenous corticoids. To investigate this possibility we assayed fetal CBG capacity and both total and free fetal plasma corticoids. Fig. 2 shows the concentration of CBG, expressed as cortisol binding capacity, in plasma of 26-d gestation fetuses. DIMIT treatment for $2 \mathrm{~d}$ increased CBG capacity in a dose-dependent manner. Cortisol capacity was $17.7 \pm 0.4 \mu \mathrm{g} / \mathrm{dl}$ with the $3 / 1.5 \mathrm{mg} / \mathrm{kg}$ DIMIT regimen compared to $8.3 \pm 0.5 \mu \mathrm{g} / \mathrm{dl}$ in control fetuses. Exposure to DIMIT for only $24 \mathrm{~h}$ produced a fetal CBG capacity of $15.9 \pm 0.8 \mu \mathrm{g} / \mathrm{dl}$ (not shown), which was equivalent to the mean value after $48 \mathrm{~h}$ treatment. To examine the specificity of this effect, we measured the levels of plasma albumin. The concentration in
DIMIT-treated fetuses $(n=28)$ was $1.51 \pm 0.03 \mathrm{~g} / \mathrm{dl}$, which was not significantly different from the mean control value $(n=20)$ of $1.49 \pm 0.05 \mathrm{~g} / \mathrm{dl}$. We also assayed CBG capacity in fetuses exposed to betamethasone, and found no effect of this treatment.

These findings are consistent with increased production of CBG, presumably in the fetal liver, after exposure to DIMIT. The increased binding of plasma corticoids by CBG would reduce the concentration of free steroid and potentially could provide a stimulus for compensatory increased secretion of adrenal

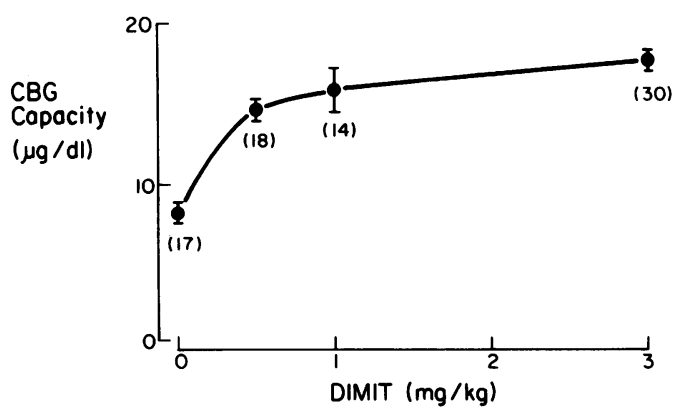

FIGURE 2 Effect of DIMIT treatment on cortisol binding capacity of 26-d gestation fetal plasma. Rabbits were treated for $2 \mathrm{~d}$ as shown in Table III, and the number of samples assayed is shown in parentheses. 
corticotropins. When a new equilibrium was reached, this series of events should produce elevated plasma concentrations of total, but not free, corticoids (41).

Fig. 3 shows the concentration of total and free corticoids in plasma of 26-d gestation fetuses after various doses of DIMIT. There was a linear increase in both total and free corticoids with increasing doses of DIMIT; at $3 \mathrm{mg} / \mathrm{kg}$ DIMIT, total and free values were 3.5 and 3.3 times the control levels, respectively. Treatment with $1 \mathrm{mg} / \mathrm{kg}$ DIMIT for $24 \mathrm{~h}$ produced somewhat lower corticoid concentrations compared to $48 \mathrm{~h}$ exposure $(P<0.05)$. Similar effects were found at $27 \mathrm{~d}$ of gestation; mean concentrations of total plasma corticoids in fetuses receiving diluent and two doses of $1 \mathrm{mg} / \mathrm{kg}$ DIMIT were $0.5 \pm 0.04$ ( $n$ $=54)$, and $1.5 \pm 0.08(n=74, P<0.001) \mu \mathrm{g} / \mathrm{dl}$, respectively.

The elevation of both total and free corticoids with DIMIT treatment suggested increased production of corticoids beyond that resulting from increased CBG binding. To evaluate the possible contribution from the maternal adrenal, we assayed corticoids in maternal plasma. At $26 \mathrm{~d}$ gestation, total corticoids in animals receiving diluent and $1 / 0.5$ and $3 / 1.5 \mathrm{mg} / \mathrm{kg}$ DIMIT were $1.6 \pm 0.3(n=9), 3.4 \pm 0.6(n=4, P<0.025)$, and $5.2 \pm 1.6 \mu \mathrm{g} / \mathrm{dl}(n=4, P<0.025)$, respectively. At $27 \mathrm{~d}$ gestation, mean values for total and free corticoids were $1.7 \pm 0.4$ and $0.4 \pm 0.1 \mu \mathrm{g} / \mathrm{dl}$ in eight control plasmas, and $5.6 \pm 0.8$ and $1.3 \pm 0.2 \mu \mathrm{g} / \mathrm{dl}(P<0.005$ for both) in nine samples from animals treated with two doses of $1 \mathrm{mg} / \mathrm{kg}$ DIMIT. We examined the time-course of this increase by serial blood sampling in two rabbits at $26 \mathrm{~d}$ of gestation that received $3 \mathrm{mg} / \mathrm{kg}$ DIMIT. Compared to preinjection corticoid values (3.2 and $2.0 \mu \mathrm{g} / \mathrm{dl})$,

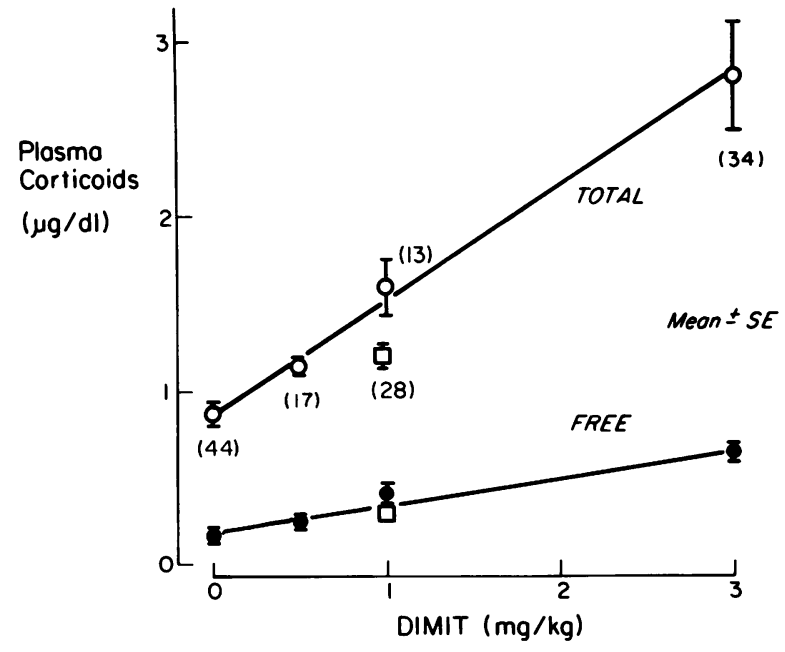

Figure 3 Effect of DIMIT treatment on total and free plasma corticoids of 26 -d gestation fetuses. Treatment was as shown in Table III; $\square$ represents one dose of $1 \mathrm{mg} / \mathrm{kg}$ DIMIT. The number of samples assayed is shown in parentheses. there was no increase in corticoids in three samples obtained during the first $2.5 \mathrm{~h}$ after injection. At $24 \mathrm{~h}$, before the second dose of DIMIT, the levels were 5.6 and $4.3 \mu \mathrm{g} / \mathrm{dl}$, and they remained elevated at $48 \mathrm{~h}$. In one animal receiving diluent there was no change in serial corticoid values.

The relationship between fetal plasma corticoids and PAPase activity in fetal lung homogenate is presented in Fig. 4. There is a direct and significant correlation between corticoid levels and PAPase activity in rabbits exposed to diluent, DIMIT, surgery with saline or prolactin injections (15), or betamethasone (25). This finding supports the proposal that higher doses of DIMIT increase PAPase activity indirectly through elevation of endogenous corticoids.

\section{DISCUSSION}

A role for thyroid hormones in fetal lung maturation is suggested by their well-known developmental effects in many organ systems, the increase in plasma $\mathrm{T}_{3}$ and $\mathrm{T}_{4}$ during late fetal life (11), the presence of nuclear $T_{3}$ receptors in fetal lung (10), and reported effects of thyroid hormones on the fetal lung (3-6). In the study by Wu et al. (3), maternal administration of $\mathrm{T}_{4}$ did not accelerate lung development, presum-

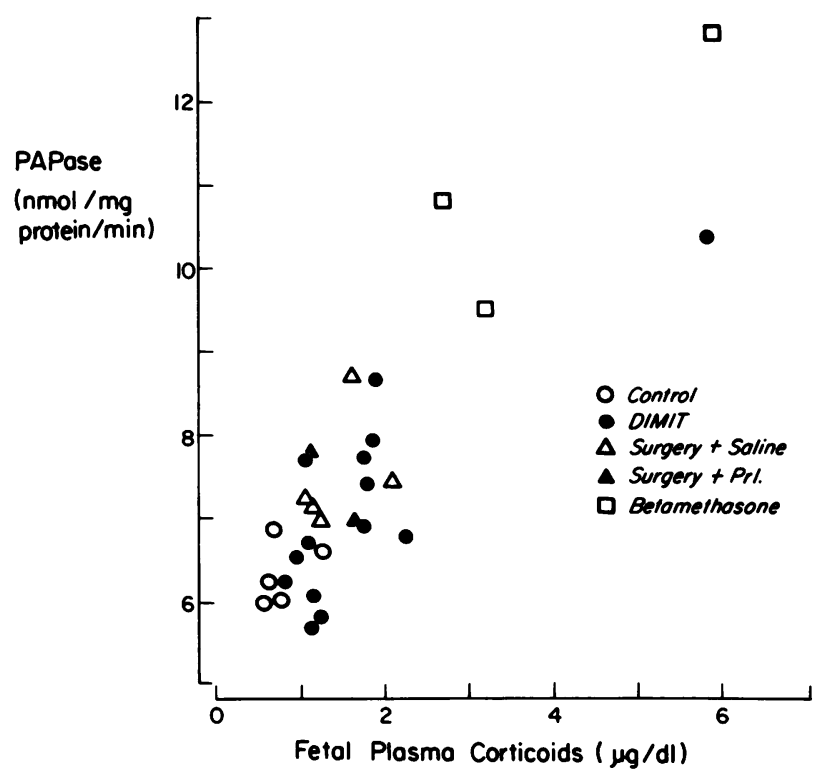

Figure 4 Relationship of fetal plasma corticoids to PAPase activity in homogenate of 26-d fetal lung. The data represent mean values for individual litters (four to eight fetuses) from rabbits receiving diluent (control), DIMIT $(0.05-3.0 \mathrm{mg} / \mathrm{kg}$ ), or surgery plus saline or prolactin ( $\mathrm{Prl})(15)$; the betamethasone data are average values for all litters after treatment for 24 (one dose) or 48 (one or two doses) h (25). The correlation coefficient is 0.86 with $P<0.01$ for all values $(n=29)$ and $0.76(P<0.01)$ excluding the betamethasone data $(n=26)$. 
ably because of limited transfer of hormone to the fetus. Similarly, in studies with fetal rats, maternal treatment with $T_{3}$ was without effect in the fetus except at doses that produced maternal hyperthyroidism $(19,20)$. Although direct injection of rabbit fetuses with $\mathrm{T}_{4}$ enhanced pulmonary development $(3,4)$, this approach is complicated by stimulatory effects of surgery and injection alone $(12-16)$. We felt that maternally administered DIMIT would avoid the complications of surgery and provide a better assessment of thyroid hormone effects in lung maturation.

Previous studies of DIMIT effects in fetal rats suggested that DIMIT freely crossed the placenta (19-21). Our studies with $\left[{ }^{3} \mathrm{H}\right]$ DIMIT confirm this property of DIMIT. The concentration of radioactivity in fetal rat plasma actually exceeded the maternal level, indicating unrestricted transfer and perhaps preferential fetal localization. The possible mechanism for a fetal:maternal gradient is not known, but conceivably might represent greater binding by proteins of fetal plasma. A similar gradient was not observed in two experiments with rabbits; this species difference may result in part from the greater concentration of serum $\mathrm{T}_{4}$-binding proteins in rabbits than in rats (42). The kinetics of radioactivity clearance from both compartments in rats indicated at least three components, and appeared to be slower in the fetus than in the mother. At the one dose investigated, clearance of DIMIT from plasma of the rat appears to be slower than reported for $T_{3}$ (43). A relatively slow clearance of DIMIT apparently also occurs in adult humans (44). The combination of higher concentrations and slower clearance of DIMIT from the fetal circulation of the rat would favor preferential effects of DIMIT in the fetus. In the studies with hypothyroid pregnant rats $(19,20)$, maternally administered DIMIT had greater effects in rat fetuses than in their mothers, consistent with higher levels of DIMIT occurring in the fetus.

On injection of DIMIT to pregnant rabbits we observed effects in both fetal liver and lung. In fetal liver, DIMIT treatment increased the activity of NADPH cytochrome $c$ reductase, decreased the glycogen content, and, presumably, stimulated synthesis of CBG. These effects on reductase activity and glycogen content were previously observed with DIMIT treatment of pregnant rats (21), and represent precocious occurrence of events normally triggered by the postnatal $\mathrm{T}_{4}$ surge (45). Thyroid hormones increase plasma CBG concentration in suckling rats (41); however, to our knowledge, this is the first indication that a similar effect can occur precociously during fetal life. These findings in fetal liver indicate that DIMIT reached the fetal circulation in concentrations sufficient to induce effects in a recognized target tissue for thyroid hormones. This dose of DIMIT for $2 \mathrm{~d}$ had no effect on fetal growth or viability, in contrast to the growth retardation and fetal wastage which occurs with betamethasone treatment $(16,25)$.

During normal development in the fetal rabbit, the rate of choline incorporation into phosphatidylcholine by fetal lung slices increases approximately fourfold from days 25-26 to 28-29 (16). We found that treatment with various doses of DIMIT increased choline incorporation by 24 to $104 \%$ at $26 \mathrm{~d}$ gestation. The increase of $104 \%$ with $3 \mathrm{mg} / \mathrm{kg}$ DIMIT was nearly double the stimulation seen with optimal doses of betamethasone in our previous study (25). These findings suggest that DIMIT treatment causes a precocious increase in the rate of phosphatidylcholine synthesis, presumably by stimulating the biosynthetic capacity in fetal lung tissue. However, it is also possible that changes in the size of substrate pools might be a factor. DIMIT decreased the glycogen content of fetal lung by $38 \%$, which is similar to the amount of depletion seen with betamethasone (16). Wu et al. (3) also noted decreased glycogen by microscopy after in utero $\mathrm{T}_{4}$ injections. These observations support the possibility that pulmonary glycogen provides substrate for phospholipid synthesis during both accelerated and normal development, and suggest that the effect of both thyroid and adrenocortical hormones on phospholipid synthesis may in part result from increased supply of glucose and other substrates.

Glucocorticoids have been reported to stimulate the activities of several enzymes of phospholipid biosynthesis in fetal rabbit lung, however, in most instances the effect remains controversial (2). We previously reported (25) that betamethasone increases the activity of microsomal PAPase in fetal lung (Table III), and this effect was confirmed by Rooney et al (16). The stimulation of PAPase by betamethasone was closely associated in regard to dosage and timecourse with the increase in rate of choline incorporation (25). By contrast, treatment with DIMIT produced a relatively small increase in tissue PAPase activity, and only at higher doses of DIMIT administered over $2 \mathrm{~d}$. Thus, the effects of DIMIT on PAPase and choline incorporation are not closely related with regard to either dosage or time-course. The longer interval required for an increase in PAPase activity suggests an indirect and secondary effect of DIMIT on this enzyme. These findings are consistent with a scheme whereby DIMIT acts directly in fetal lung to stimulate phosphatidylcholine synthesis, at a biochemical site not involving PAPase, and also enhances the production and release of corticosteroids through effects elsewhere in the fetus and/or mother. The eventual rise in endogenous plasma corticoids would then induce PAPase in the fetal lung. If glucocorticoids and thyroid hormones do act through different biochemical mechanisms to stimulate phospholipid synthesis, then it is possible that administration of 
both hormones together would produce an additive effect. This proposal is supported by the reported interaction of steroids and $T_{3}$ in other systems (46-49).

DIMIT treatment increased the content of total phospholipid in lavage by $>150 \%$, compared to a $50 \%$ increase with $0.1 \mathrm{mg} / \mathrm{kg}$ betamethasone. Rooney et al. (16) also found a $50 \%$ increase in total phospholipid with $0.2 \mathrm{mg} / \mathrm{kg}$ betamethasone. DIMIT also increased the amount of both saturated phosphatidylcholine $(+330 \%)$ and PAPase activity $(+134 \%)$ in lavage fluid, indicating an increased amount of surface active material in alveolar spaces.

An increase in plasma corticoids was not anticipated before initiating the study, however, such an effect was suggested by the increase in PAPase activity of lung homogenate after treatment with DIMIT. The corticoid increase was not a stress response to injections; control animals received the same volume of diluent and no immediate increase in corticoids was observed in two animals receiving DIMIT. Administration of $\mathrm{T}_{4}$ to suckling rat pups increases both stressed and basal levels of total corticosterone after 4 and $9 \mathrm{~d}$ treatment, respectively (50); this increase apparently results from enhanced levels of CBG (41). Although plasma CBG increased in DIMITtreated fetuses, this should not in itself result in higher levels of "free" corticoids (41). In humans, hyperthyroidism increases both the turnover rate and the secretion rate of cortisol, but does not affect plasma levels (51). Regardless of the mechanism, it is likely that DIMIT acts in the mother, since the percentage of increase in corticoid levels was similar in fetal and maternal circulation. DIMIT may also act directly in the fetus, however, fetal effects alone should not produce an equivalent percentage increase in maternal plasma corticoids.

The rise in endogenous fetal corticoids raises the question as to their role in the effects observed with DIMIT treatment. Several lines of evidence indicate that DIMIT has actions in the fetus that are independent of steroid effects. The increase of both liver NADPH cytochrome $c$ reductase activity and plasma CBG capacity are presumably direct effects of DIMIT, since neither reductase activity (45) nor CBG levels in the fetus are influenced by glucocorticoids. In fetal lung, lower doses of DIMIT markedly increased choline incorporation without affecting the activity of PAPase, an enzyme which is apparently responsive to both exogenous and endogenous glucocorticoids. Finally, the increase in both choline incorporation and lavage phospholipid with DIMIT treatment was significantly greater than occurred with optimal doses of betamethasone.

On the other hand, it is likely that endogenous corticoids contribute to the effects observed in fetal lung at higher doses of DIMIT. With the 1 and $3 \mathrm{mg} / \mathrm{kg}$ regimens of DIMIT, PAPase activity in lung homogenate increased 11 and $38 \%$, respectively, presumably as a result of the higher plasma corticoid levels. Because the stimulation of PAPase activity by betamethasone is similar in magnitude to the effect observed on choline incorporation (25), it may be estimated that endogenous corticoids account for less than one-third of the increase in rate of choline incorporation after DIMIT treatment. Similarly in lavage fluid, based on the effect observed with betamethasone, endogenous corticoids would appear to account for one-third or less of the increase in phospholipid content seen with DIMIT. A direct mode of action by DIMIT is also supported by the previous observation that $T_{4}$ stimulates the rate of choline incorporation by fetal rabbit lung cells in culture (5). These considerations strongly suggest that most of the effects observed with DIMIT are mediated by a mechanism independent of glucocorticoids.

We have previously proposed that DIMIT and other thyroid hormones may act via nuclear receptors in fetal lung to induce enzymes involved in the synthesis of surfactant (10). This study suggests that thyroid hormone affects enzyme(s) different from those stimulated by glucocorticoids. If this is the case, corticosteroids and thyroid hormones may have complementary and additive effects on lung maturation. DIMIT will be useful in exploring this possibility further. Moreover, thyroid hormone analogues of this type may eventually find application in prenatal prevention of hyaline membrane disease in human infants.

\section{ACKNOWLEDGMENTS}

We thank T. Sargeant and J. Ruch for technical assistance, and Dr. R. Lemmon, Lawrence Laboratories, Berkeley, Calif., for his cooperation in performing the tritium exchange and Dr. A. Gallo for his assistance in purifying $\left.{ }^{3} \mathrm{H}\right]$ DIMIT.

This study was supported by Program Project grant HL06285, Pulmonary Specialized Center of Research grant HL-19185 from the National Heart, Lung, and Blood Institute, and U. S. Public Health Service grant AM-17576.

\section{REFERENCES}

1. Ballard, P. L., A. Brehier, B. J. Benson, B. M. Kriz, and E. C. Jorgensen. 1978. Transplacental effects of a thyroxine analog on phospholipid synthesis in fetal rabbit lung. Pediatr. Res. 12: 558. (Abstr.)

2. Ballard, P. L., B. J. Benson, and A. Brehier. 1977. Glucocorticoid effects in the fetal lung. Am. Rev. Resp. Dis. 115: 29-36.

3. Wu, B., Y. Kikkawa, M. M. Orzalesi, E. K. Motoyama, M. Kaibara, C. J. Zigas, and C. D. Cook. 1973. The effect of thyroxine on the maturation of fetal rabbit lungs. Biol. Neonate. 22: 161-168.

4. Rooney, S. A., I. Gross, L. N. Gassenheimer, and E. K. Motoyama. 1975. Stimulation of glycerolphosphate phosphatidyltransferase activity in fetal rabbit lung by 
cortisol administration. Biochim. Biophys. Acta. 398: 433-441.

5. Smith, B. T., and J. S. Torday. 1974. Factors affecting lecithin synthesis by fetal lung cells in culture. Pediatr. Res. 8: 848-851.

6. Erenberg, A., M. L. Rhodes, M. W. Weinstein, and R. L. Kennedy. 1979. The effect of fetal thyroidectomy on ovine fetal lung maturation. Pediatr. Res. 13: 230-235.

7. Redding, R. R., and C. Pereira. 1974. Thyroid function in respiratory distress syndrome (RDS) of the newborn. Pediatrics. 54: 423-428.

8. Cuestas, R. A., A. Lindall, and R. R. Engel. 1976. Low thyroid hormones and respiratory distress syndrome of the newborn. Studies on cord blood. N. Engl. J. Med. 295: 297-302.

9. Mashiach, S., G. Barkai, J. Sack, E. Stern, M. Brish, B. Goldman, and D. M. Serr. 1979. The effect of intraamniotic thyroxine administration on fetal lung maturity in man. J. Perinat. Med. 7: 161-170.

10. Lindenberg, J. A., A. Brehier, and P. L. Ballard. 1978. Triiodothyronine nuclear binding in fetal and adult rabbit lung and cultured lung cells. Endocrinology. 103: 1725-1731.

11. Fisher, D. A., J. H. Dussault, J. Sack, and I. J. Chopra. 1977. Ontogenesis of hypothalamic-pituitary-thyroid function and metabolism in man, sheep, and rat. Recent Prog. Horm. Res. 33: 59-116.

12. Russell, B. J., L. Nugent, and V. Chernick. 1974. Effects of steroids on the enzymatic pathways of lecithin production in fetal rabbits. Biol. Neonate. 24: 306-314.

13. Robert, M. F., A. T. Bator, and H. W. Taeusch, Jr. 1975. Pulmonary pressure-volume relationships after corticotropin (ACTH) and saline injections in fetal rabbits. Pediatr. Res. 9: 760-762.

14. Rooney, S. A., L. Gobran, I. Gross, T. S. Wai-Lee, L. L. Nardone, and E. K. Motoyama. 1976. Studies on pulmonary surfactant. Effects of cortisol administration to fetal rabbits on lung phospholipid content, composition and biosynthesis. Biochim. Biophys. Acta. 450: 121-130.

15. Ballard, P. L., P. D. Gluckman, A. Brehier, J. A. Kitterman, S. L. Kaplan, A. M. Rudolph, and M. M. Grumbach. 1978. Failure to detect an effect of prolactin on pulmonary surfactant and adrenal steroids in fetal sheep and rabbits. J. Clin. Invest. 62: 879-883.

16. Rooney, S. A., L. I. Gobran, P. A. Marino, W. M. Maniscalco, and I. Gross. 1979. Effects of betamethasone on phospholipid content, composition and biosynthesis in fetal rabbit lung. Biochim. Biophys. Acta. 572: 64-76.

17. Snyder, S. M., R. R. Cavalieri, I. D. Goldfine, S. H. Ingbar, and E. C. Jorgensen. 1976. Binding of thyroid hormones and their analogues to thyroxine-binding globulin in human serum. J. Biol. Chem. 251: 6489-6496.

18. Jorgensen, E. C., W. J. Murray, and P. Block, Jr. 1974. Thyroxine analogs. XXII. Thyromimetic activity of halogen-free derivatives of 3,5-dimethyl-L-thyronine. J. Med. Chem. 17: 434-439.

19. Comite, F., G. N. Burrow, and E. C. Jorgensen. 1978. Thyroid hormone analogs and fetal goiter. Endocrinology. 102: $1670-1674$.

20. Benson, M. C., J. P. Liu, Y. P. Huang, A. Burger, and R. S. Rivlin. 1978. Differential effects of triiodothyronine and 3,5-dimethyl-3'-isopropyl-L-thyronine treatment of maternal rats upon hepatic L-triiodothyronine aminotransferase activity in fetal rats. Endocrinology. 102: 562-567.

21. Kriz, B. M., A. L. Jones, and E. C. Jorgensen. 1978. Effects of a thyroid hormone analog on fetal rat hepatocyte ultrastructure and microsomal function. Endocrinology. 102: 712-722.

22. Frieden, E., and K. Yoshizato. 1974. Thyromimetic activity of methyl thyronines in bullfrog tadpole. Endocrinology. 95: 188-194.

23. Hembree, W. C., R. E. Ehrenkaufer, S. Lieberman, and A. P. Wolf. 1973. A general method of tritium labeling utilizing microwave discharge activation of tritium gas. J. Biol. Chem. 248: 5532-5540.

24. Upton, R. A. 1975. Simple and reliable method for serial sampling of blood from rats. J. Pharm. Sci. 64: 112-114.

25. Brehier, A., B. J. Benson, M. C. Williams, R. J. Mason, and P. L. Ballard. 1977. Corticosteroid induction of phosphatidic acid phosphatase in fetal rabbit lung. Biochem. Biophys. Res. Commun. 77: 883-890.

26. Roehrig, K. L., and J. B. Allred. 1974. Direct enzymatic procedure for the determination of liver glycogen. Anal. Biochem. 58: 414-421.

27. Lowry, O. H., N. J. Rosebrough, A. C. Carr, and R. J. Randall. 1951. Protein measurement with the Folin phenol reagent. J. Biol. Chem. 193: 265-275.

28. Giles, K. W., and A. Meyer. 1965. An improved diphenylamine method for the estimation of deoxyribonucleic acid. Nature (Lond.). 206: 93.

29. Bartlett, G. R. 1959. Phosphorus assay in column chromatography. J. Biol. Chem. 234: 466-468.

30. Mason, R. J., J. Nellenbogen, and J. A. Clements. 1976. Isolation of disaturated phosphatidylcholine with osmium tetroxide. J. Lipid Res. 17: 281-284.

31. Zakim, D., and D. A. Vessey. 1973. Techniques for the characterization of UDP-glycuronyltransferase, glucose6-phosphatase, and other tightly bound microsomal enzymes. Methods Biochem. Anal. 21: 1-37.

32. Masters, B. S., C. H. Williams, Jr., and H. Kamin. 1967. The preparation and properties of microsomal TPNHcytochrome $\mathrm{C}$ reductase from pig liver. Methods Enzymol. 10: 565-573.

33. Folch, J., M. Lees, and G. H. Sloane Stanley. 1957. A simple method for the isolation and purification of total lipids from animal tissues. J. Biol. Chem. 226: 497-509.

34. Baginski, E., and B. Zak. 1960. Microdetermination of serum phosphatase and phospholipids. Clin. Chem. Acta. 5: 834-843.

35. Poorthuis, B. J. H. M., P. J. Yazaki, and K. Y. Hostetler. 1976. An improved two dimensional thin-layer chromatography system for the separation of phosphatidylglycerol and its derivatives. J. Lipid Res. 17: 433-437.

36. Mescher, E. J., A. C. G. Platzker, P. L. Ballard, J. A. Kitterman, J. A. Clements, and W. H. Tooley. 1975. Ontogeny of tracheal fluid, pulmonary surfactant and plasma corticoids in the fetal lamb. J. Appl. Physiol. 38: $1017-1021$.

37. Doumas, B. T., W. A. Watson, and H. G. Biggs. 1971. Albumin standards and the measurement of serum albumin with bromcresol green. Clin. Chem. Acta. 31: $87-96$.

38. Tait, J. F., and S. Burnstein. 1964. In vivo studies of steroid dynamics in man. In The Hormones. G. Pincus, K. V. Thimann, and E. B. Astwood, editors. Academic Press, Inc., New York. 5: 441-557.

39. Spitzer, H. L., and J. M. Johnston. 1978. Characterization of phosphatidate phosphohydrolase activity associated with isolated lamellar bodies. Biochem. Biophys. Acta. 531: 275-285.

40. Herbert, W. N. P., J. M. Johnston, P. C. MacDonald, and J. M. Jimenez. 1978. Fetal lung maturation. Human amniotic fluid phosphatidate phosphohydrolase activity through normal gestation and its relation to the lecithin/ 
sphingomyelin ratio. Am. J. Obstet. Gynecol. 132 : 373-379.

41. Thomas, A. L., C. G. Horn, and P. W. Nathanielsz. 1980. The development of the thyroid-adrenal interrelationship in the newborn rat from birth to 30 days of age. J. Endocrinol. In press.

42. Sutherland, R. L., and M. R. Brandon. 1976. The thyroxine-binding properties of rat and rabbit serum proteins. Endocrinology. 98: 91-98.

43. Chen, H. J., and P. G. Walfish. 1978. Effects of estradiol benzoate on thyroid-pituitary function in female rats. Endocrinology. 103: 1023-1030.

44. Tamanga, E. I., J. M. Hershman, and E. C. Jorgensen. 1979. Thyrotropin suppression by 3,5-dimethyl-3'-isopropyl-L-thyronine in man. J. Clin. Endocrinol. Metab. 48: $196-200$.

45. Greengard, O., and H. K. Dewey. 1968. The developmental formation of liver glucose 6-phosphatase and reduced nicotinamide dinucleotide phosphate dehydrogenase in fetal rats treated with thyroxine. J. Biol. Chem. 243: 2745-2749.

46. Martial, J. A., P. H. Seeburg, D. Guenzi, H. M. Goodman, and J. D. Baxter. 1977. Regulation of growth hormone gene expression: synergistic effects of thyroid and glucocorticoid hormones. Proc. Natl. Acad. Sci. U. S. A. 74: 4293-4295.

47. Śhapiro, L. E., H. H. Samuels, and B. M. Yaffe. 1978. Thyroid and glucocorticoid hormones synergistically control growth hormone mRNA in cultured $\mathrm{GH}_{1}$ cells. Proc. Natl. Acad. Sci. U. S. A. 75: 45-49.

48. Perrone, M. H., and P. M. Hinkle. 1978. Regulation of pituitary receptors for thyrotropin-releasing hormone by thyroid hormones. J. Biol. Chem. 253: 5168-5173.

49. Takuma, T., and M. Kumegawa. 1979. Synergistic effects of thyroxine and glucocorticoid in induction of trypsinlike esteroprotease in mouse submandibular gland. Biochim. Biophys. Acta. 584: 51-56.

50. Poland, R. E., M. E. Weichsel, Jr., and R. T. Rabin. 1979. Postnatal maturation patterns of serum corticosterone and growth hormone in rats: effect of chronic thyroxine administration. Horm. Metab. Res. 11: 222-227.

51. Gordon, G. G., and A. L. Southren. 1977. Thyroidhormone effects on steroid-hormone metabolism. Bull. N. Y. Acad. Med. 53: 241-259. 